\title{
HIERACIA BALCANICA XII. OLDEST COLLECTION OF HIERACIUM ALPINUM (ASTERACEAE) FROM THE BALKAN PENINSULA
}

\author{
ZBIGNIEW SZELĄG
}

Zbigniew Szelag, Pedagogical University of Cracow, Department of Botany, Podchorążych 2, 30-084 Kraków, Poland; e-mail: azszelag@wp.pl

Hieracium alpinum L. is a common species occurring in the highest, siliceous mountains of Central Europe (Alps, Harz, Carpathians, Sudetes) and in Northern Europe (Greenland, Island, Scandinavia, British Islands, Ural Mts) (Bräutigam 1992). Its southernmost, disjoined localities are on the Apennine Peninsula and Balkan Peninsula. The only Balkan occurrence of $H$. alpinum is in the Vranica Mts in Bosnia and Herzegovina, found in 1938 (Horvat \& Pawłowski 1939). Pawłowski’s publication from 1963 is the recognized source (cf. Bräutigam 1992: 328), even though Pawłowski
(1963: 482) wrote that together with Horvat he published the first information on $H$. alpinum in the Vranica Mts in 1939.

Hieracium alpinum is quite frequent in the Vranica Mts. The plants from the Vranica Mts were found to be triploid (Ilnicki \& Szeląg 2011) like the majority of those in the European range of the species. The diploids are confined to the Eastern and Southern Carpathians (Mráz \& Szeląg 2004).

During a revision of Hieracium collection in the Moravian Museum in Brno (BRNM) I found two herbarium sheets of $H$. alpinum also collected

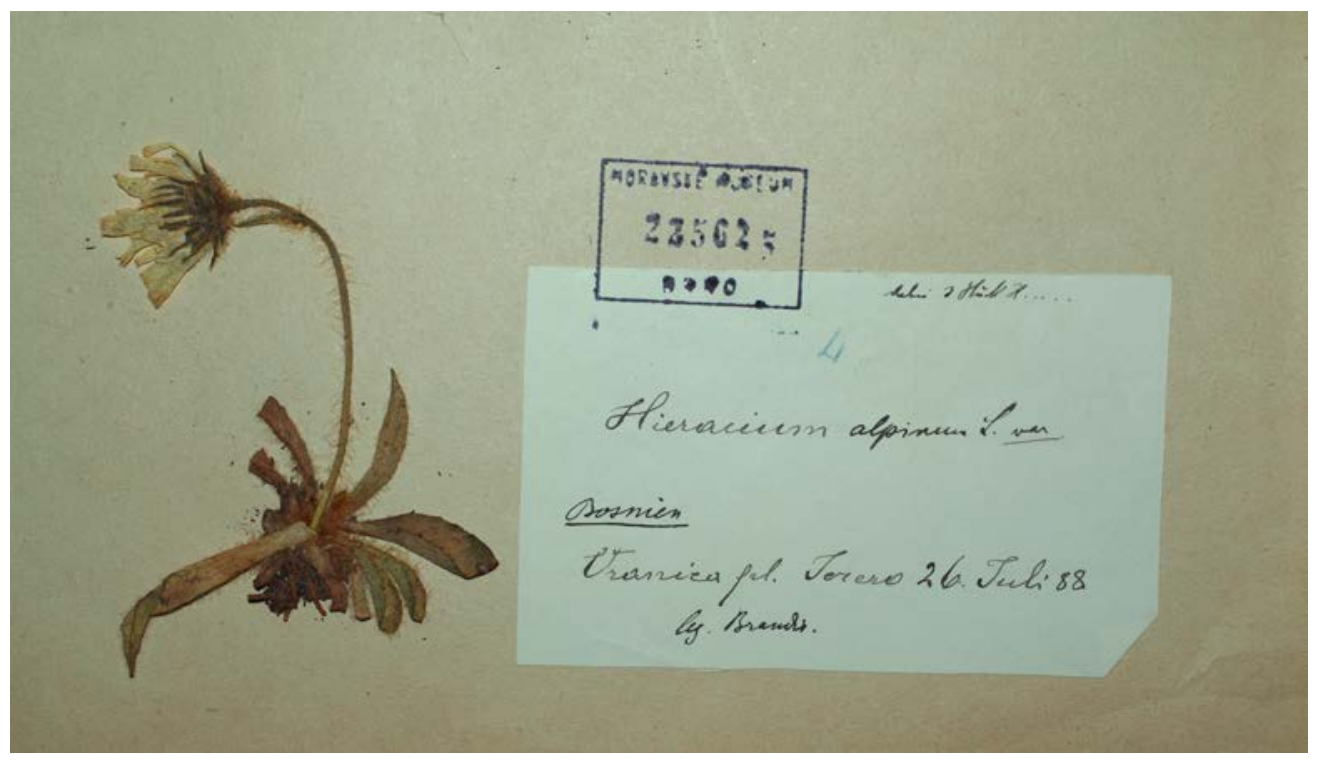

Fig. 1. Specimen of Hieracium alpinum L. collected by Erich Brandis in Bosnia (BRNM 225625). 
in the Vranica Mts, but half a century earlier: in 1888 by Erich Brandis. The first sheet (BRNM 225625) comprises one specimen of $H$. alpinum (Fig. 1). On the second one (BRNM 69450) the $H$. alpinum specimen is mounted among a few specimens of $H$. morisianum subsp. villosiceps (Nägeli \& Peter) Zahn. Both H. alpinum specimens were collected on July 26, 1888, at the same locality: Bosnia, Vranica planina, [Prokoško] Jezero.

Erich Maria Heinrich Joseph Franz von Sales Graf zu Brandis, a Jesuit priest, was born in Betnava (Windenau) near Maribor, Slovenia, on April 30, 1834. He died on January 3, 1921, in Travnik, Bosnia and Herzegovina, and was buried in the Bojna cemetery (Balabanić 1992). A professor for nearly 40 years in the Archdiocesan Seminary and Secondary School in Travnik (Nadbiskupsko sjemenište i Nadbiskupska velika gimnazija u Travniku) Brandis carried out floristic, faunistic and geomorphological research in Bosnia and Herzegovina, making many significance discoveries (Brandis 1890, 1891, 1892; Freyn \& Brandis 1888; Gutwiński 1898). His most important botanical publications are Botanische Beiträge zur Flora von Travnik in Bosnien (Brandis 1891) and Beitrag zur Flora von Bosnien und der angrenzenden Hercegovina (Freyn \& Brandis 1888).

Numerous specimens collected by Brandis in Bosnia and Herzegovina were disseminated in the Baenitz Herbarium Europaeum exsiccate series.

Brandis' herbarium is now housed at the National Museum in Sarajevo (SARA) (Riter 1951).

AcKNowledgements. I am grateful to Dr. Karel Sutorý (Curator of BRNM) for making the relevant collections available for study, to Dr. Igor Malenovský for his kindness and help during my visit to BRNM, and to the anonymous referee for helpful suggestions on the manuscript.

\section{REFERENCES}

BALABANIć J. 1992. The life and work of Father Erik Brandis, S.J., naturalist, professor and collector. In: V. PozAić (ed.), Jesuits among the Croats: proceedings of the International Symposium Jesuits in the religious, scientific and cultural life among the Croats. (Zagreb, Croatia, October 8-11, 1990), pp. 147-159. Filozofsko-teološki Institut Družbe Isusove, Zagreb.

Brandis E. 1890. Koleopteri u srednjoj Bosni. Glasnik Zemaljskog Muzeja u Bosni i Hercegovini 2(2): 177-187.

BRANDIs E. 1891. Botanische Beiträge zur Flora von Travnik in Bosnien. Jahrbuch des Naturwissenschaftliche Vereines Trencsiner Comitates 13/14: 49-78.

Brandis E. 1892. Central-Bosnien. Geognostische Beobachtungen angestellt an der nun in Angriff genommenen Bahnstrecke Janjići-Travnik-Bugojno. Jahrbuch des $\mathrm{Na}$ turwissenschaftliche Vereines Trencsiner Comitates 15: 82-91.

Bräutigam S. 1992. Hieracium L. In: H. Meusel \& E. J. JÄGER (eds), Vergleichende Chorologie der zentraleuropäischen Flora. 3: 325-333. Gustav Fischer, Jena.

Freyn J. \& Brandis E. 1888. Beitrag zur Flora von Bosnien und der agrezenden Hercegovina. Verhandlungen des zoologisch-botanischen Vereins in Wien 38: 577-644.

GuTwiŃsKi R. 1898. O algama sabranim oko Travnika po velečasnom prof. Eriku Brandisu. Glasnik Zemaljskog Muzeja u Bosni i Hercegovini 10: 247-263.

Horvat I. \& Pawıowski B. 1939. Istraživanje vegetacije Planine Vranice. Ljetopis Jugoslav. Akad. Znan. Umjet. Zagreb 51: 149-152.

IlniCKI T. \& SzeląG Z. 2011. Chromosome numbers in Hieracium and Pilosella (Asteraceae) from Central and Southeastern Europe. Acta Biol. Cracov. Ser. Bot. 53(1): $102-110$.

Mráz P. \& SzeląG Z. 2004. Chromosome numbers and reproductive systems in selected species of the genera Hieracium L. and Pilosella Hill (Asteraceae) from Romania. Ann. Bot. Fenn. 41: 405-414.

Pawıowski B. 1963. Hieracia balcanica nova vel minus cognita. Acta Soc. Bot. Poloniae 32: 473-491.

Riter H. 1951. Prenos Brandisova herbara iz Travnika u Sarajevo. God. Biol. Inst. u Sarajevu 4: 115-119. 